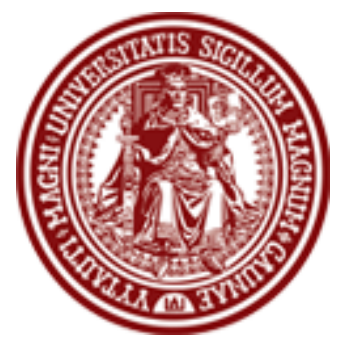

BALTIC JOURNAL OF LAW \& POLITICS

VOLUME 6, NUMBER 2 (2013)

ISSN 2029-0454

http://www.degruyter.com/view/j/bjlp

Cit.: Baltic Journal of Law \& Politics 6:2 (2013): 75-101

DOI: $10.2478 /$ bjlp-2013-0012

\title{
THE EU'S NEIGHBORHOOD POLICY TOWARDS THE SOUTHERN CAUCASUS: SEARCHING FOR COMMONALITY IN A PATCHY \\ SCENARIO
}

\author{
Sanda-Daniela Alexeiciuc \\ Director; MA in Human Rights \\ Center of Development of Health and Education (CEDES) (Moldova) \\ Yerevan State University Center of European Studies (Armenia) \\ Contact information \\ Address: office \#4, 60 Mateevici, Chisinău, Moldova \\ Phone: +79211979197 \\ E-mail address: danielaalexeiciuc@gmail.com
}

\section{Kirill N. Babichenko}

Executive Director; Assistant Professor of Law, Ph.D.

Center of Development of Health and Education (CEDES) (Moldova)

Russian State Humanitarian University (Russian Federation)

Contact information

Address: office \#8, 25 Germana, Velikiy Novgorod, Russian Federation

Phone: +79211942942

E-mail address: kbabichenko@gmail.com

Received: October 19, 2013; reviews: 2; accepted: December 16, 2013.

\section{ABSTRACT}

The paper explains the difficulties that have been emerging for the Southern Caucasus regarding these countries' relationship with and towards the EU. Through the deconstruction of the area's particularities and specificities, and its framing in the EU's policy to the region, this paper aims at analyzing the implications of the transition efforts and stability in the area for Europe in general, along with the different roles each of these pieces - Armenia, Azerbaijan and Georgia - play in the complex strategic Caucasian puzzle. 
Thus, the EU's neighborhood policy goals are closely interconnected with the principles defined in the Union's security strategy, demonstrating the commonly felt need for the building of stability in its vicinity as a way of promoting and expanding security.

\section{KEYWORDS}

International politics, security, democratization, cooperation, socio-economic, negotiation 


\section{INTRODUCTION}

The uncertainties in the new international order, marked by growing interdependence as a result of the processes of globalization, along with fragmentation tendencies, together with the numerous threats to international security, contribute to the complexity of the international scenario, launching questions about the balancing of norms and interests, and the juxtaposition and coordination of objectives and resources. In this context, the clarification of the relationship between the European Union (EU) and the Caucasus, through the identification of competing interests and cooperation opportunities, along with the analysis of the agendas of these distinct actors, are relevant for the understanding of the EU's eastern neighborhood policy in a politico-institutional and security perspective.

The southern Caucasus, including Armenia, Azerbaijan and Georgia, despite its commonly applied label, is a heterogeneous region where these three different states present different political and institutional stages of development, distinct political cultures, and disparate paths in their transition courses towards democratization. This implies complexity in any policy directed at the region, since a multilevel and encompassing approach to the problems is demanded.

In this context, from words to action many difficulties have been emerging regarding these countries' relationship with and towards the EU. The general guidelines defined and the patchy and volatile situation in the southern Caucasus have raised numerous interrogations about the applicability, sustainability and viability of a EU policy of cooperation to the area along with the differentiated responses and expectations from the envisaged countries towards the proposals and measures which have emerged. To which extent might cooperation prevail in the midst of competing interests? How far might the Caucasus' different conjugations of interests and practices affect the region's relations with the EU? What impact might EU policies towards the area have in building security and stability, at the political-institutional level? How might the Union's democracy building instruments assist the transition courses in the southern Caucasus? In this process, to which extent the deep differences in the stages of transition, the diverging interpretations about the post-Soviet reality and the interlinkages between the internal and external developments within these countries and between them make a difference? How far are intra and inter-state conflicts in the area affected by the Union's strategy towards the region? Which is better: enhancing security and raising stability, or instead fostering competition and rivalry 
in a much contested game? By searching for answers to these questions, this paper aims at analyzing the complex context in which the EU-Caucasus relationship takes place, looking for possible ways ahead in the building of cooperation and the fostering of democratization, and in the finding of a balance necessary for constructing stability throughout Europe.

\section{THEORETICAL CONTEXTUALIZATION: FRAMING NEIGHBORHOOD} RELATIONS IN A NORMATIVE CONCEPTUALIZATION

The political development of Europe in a time of profound changes, including institutional reform and a new wave of enlargement, in a difficult socio-economic setting, needs solid foundations. The definition of a common security and defense strategy is a fundamental pillar in this foundations' structure. This political construction, strongly impelled by the Second World War is not yet complete. The inclusion of ten new countries from May 2004, Romania and Bulgaria's accession from 2007, and the discussions leading to agreement on a new Constitutional Treaty, ${ }^{2}$ currently at a standstill, reflect the dynamism inherent to the European process. However, the political-military dimension has not matched the economic weight of the EU, a weakness since its outset which has become more acute with the passing of time and the changing international circumstances. The end of the bipolar rivalry and the delineation of a new world order after the cold war have demonstrated the much fragility embodying the Union, which despite being a global economic force, in political terms remains a regional power.

The post-cold war order offered new rules for the international game, requiring adjustments to the new conditions. In this new setting, the European Union has increasingly gained relevance and international capacity to act in external affairs. The policy of enlargement has been a concrete example of EU's external action, and of how it has been promoting and supporting transition efforts towards democracy and functioning market economies. Moreover, in its new geographical limits, the EU has empowered a cooperative approach towards its neighbors, in order to avoid feelings of exclusion or eventually create a new division line in Europe between those "in" and those "out", through, for example, the negotiation and signing of association and cooperation agreements with the former Soviet republics and Russia. This developmental approach has been extended to other regions, in particular Africa and the Middle East, and has also included trade negotiations and environmental measures agreed within the framework of multilateral fora. This demonstrates the wide engagement of the EU at the global

\footnotetext{
${ }^{1}$ The Czech Republic, Cyprus, Estonia, Hungary, Latvia, Lithuania, Malta, Poland, Slovakia and Slovenia.

${ }^{2}$ Agreement reached at the Brussels Council, June 2004.
} 
level, allowing the acknowledgement of the Union as an active foreign policy actor. We will here concentrate on a sub-dimension of European foreign policy, problematizing security within the broader framework of the CFSP, with a clear emphasis on stabilization, transition and democratization.

Security is a complex and dynamic concept that includes interdisciplinary and integrative aspects. It is understood as a multi-faceted term covering a wide range of military and non-military challenges with wide implications for international, national and regional peace and stability. It is transversal regarding international actors, of a governmental and non-governmental nature, and the decision-making centers from the highest level of the state to its regional dimensions, taking place in a bilateral or multilateral context, as a way of responding to a multiplicity of relations, pressure factors and leverage power to direct, or at least, condition change. In addition, there is a clear linkage between internal and external threats to security, which render the concept added complexity in its understandings and dealings. The feelings of insecurity associated to the terrorist attacks in the United States in September 2001 followed by attacks in Europe (such as in Madrid and London), attest the pertinence of this encompassing understanding of security, as well as the need for encompassing responses to these global threats.

The EU as a security community shares a set of values and norms built on a soft and multilateral approach to security, from which benefit-driven outputs are both an end and a self-sustaining factor, both for the Union and for the promotion of security in its vicinity. "If we consider security as a matter of dialogue, exchange, trust building and civilian action more than military superiority, then the EU has a role to play." 3 These soft security areas, where the EU has increasingly been gaining relevance, are fundamental as a basis for the Union's involvement at the global level, and for its influence as a "normative model" ${ }^{4}$. By a process of gradual socialization of security approaches, meaning a set of norms and values allowing an approximation to EU policies and ways of dealing, it aims at endorsing an enlarged security community in its still much uncertain neighborhood.

\section{THE EU'S STRATEGY TOWARDS THE CAUCASUS}

The EU's presence in the south Caucasus goes back to the early days after the break-up of the Soviet Union. ${ }^{5}$ As a part of the stabilization approach developed by the EU for the region, humanitarian aid and technical assistance programs were

${ }^{3}$ Frédéric Charillon, "The EU as a Security Regime," European Foreign Affairs Review No. 10 (2005): 522.

${ }^{4}$ Richard Youngs, "The ESDP: What Impact on the EU's Approach to Security Challenges?" European Security Vol.11 (2) (2002): 103.

${ }^{5}$ Brian White, "Foreign Policy Analysis and the New Europe"; in: Walter Carlsnaes, Helen Sjursen, and Brian White, eds., Contemporary European Foreign Policy (SAGE Publications, 2004). 
implemented. These were impelled by both the Union's "Russia first" strategy, demonstrating the EU understanding of the relevance of its relations with Moscow, for various reasons, including the role it might play in the broader framing of the Union's further engagement within the former Soviet space (it should be noted that for long Russia remained the privileged partner in the area and only recently did the EU furthered its relations with the other independent republics in the former Soviet area); and by the conflicts ravishing the region, which allowed generalized instability close to the EU borders. In 1999, Partnership and Cooperation Agreements (PCA) between the Union and Armenia, Azerbaijan and Georgia entered into force, creating a platform for dialogue on political and economic issues, and eventually contributing to the fostering of regional cooperation. ${ }^{6}$ However, the results of this cooperation were limited to low levels of harmonization due to difficulties regarding the implementation of reforms, and mostly to the inability of the EU to address the root causes of regional instability, in particular the intra-state conflicts in Georgia and the inter-state dispute between Armenia and Azerbaijan over Nagorno-Karabakh. ${ }^{7}$

The development of civilian and military capabilities for external action within the EU, and the expansion of its legal and institutional boundaries were prompted by a set of perceived changes in the international context, most notably the end of the Soviet Union, the September 11 attacks and the global war on terror, as well as events in its periphery, of particular relevance here, the "Rose Revolution" in Georgia. These prompted the Union's attention and further awareness of the southern Caucasus as an area of strategic relevance in political, economic and security terms, a realization that was consubstantiated in the region's inclusion in the European Neighborhood Policy (ENP).

The EU's neighborhood policy, first crafted by a Communication from the European Commission about an enlarged Europe in March 2003, and further consolidated in July the same year, ${ }^{8}$ offers cooperation in three main areas: a political, human, civil and cultural dimension; a security one; and sustainable economic and social development, with the aim at establishing a "friendship ring" in the EU's borders. In May 2004 a Strategy Paper was approved defining closer collaboration between the Union and its neighbors, and including the drafting of

${ }^{6}$ Ivan Samson and Olena Vasylchenko, "EU PCA and ENP Policies for Georgia: How Economic Interaction with the European Union May Ease the Reform Process and Economic Development in Georgia," Georgian Economic Quarterly Review 4 (2004).

${ }^{7}$ As noted in a Communication from the Commission on EU relations with the South Caucasus under the PCA of June 1999 and the Joint Luxemburg Declaration by the EU and the Heads of State of Armenia, Azerbaijan and Georgia.

8 Wider Europe Neighbourhood: A New Framework for Relations with our Eastern and Southern Neighbors, Communication from the Commission, COM (March 2003) 104, 11; Paving the Way for a New Neighbourhood Instrument: A New Framework for Relations with our Eastern and Southern Neighbours, Communication from the Commission (July 1, 2003). 
Country Reports with a bilateral character and according to the most pressing needs of each of these countries, reflecting the political, economic, social and institutional situation in these countries as a basis for the definition of the Action Plans. These "suited to fit" Action Plans aim at bridging the differences between needs and capabilities, establishing concrete and simultaneously ambitious targets in distinct areas for an integrated development of each of these partners, particularly in the process of politico-economic and democratic transition. "The EU wishes to see reinforced, credible and sustained commitment towards democracy, the rule of law, respect for human rights, and progress towards the development of a market economy." The Paper adds emphasis to strengthening the rule of law and promoting conflict settlement, along with an explicit reference to the issue of energy "as the southern Caucasus is an important region both for the production (the Caspian basin) and the transit of energy". ${ }^{9}$

According to EU sources, these measures envisage the building of an enlarged area of stability and security on the basis of confidence and the sharing of common values, eventually allowing more efficacy in the combat against the new menaces, particularly terrorism and organized crime. In this way, the Union's neighborhood policy aims at the promotion of stability, well-being and security defined by the three Ps: proximity, prosperity and poverty, independently of these states being or not considered as eventual candidates at formal integration. It aims at avoiding new dividing lines between an enlarged Europe and its neighbors, responding directly to the objective of the European Security Strategy of constructing stability in the neighboring area of the Union.

The EU neighborhood policy includes six countries from the former Soviet space (Belarus, Moldova, Ukraine, and from the southern Caucasus, Georgia, Armenia and Azerbaijan) and nine plus one in the Mediterranean area (Algeria, Egypt, Israel, Jordan, Lebanon, Libya, Morocco, Syria and Tunisia plus the Palestinian Authority). The inclusion of the southern Caucasus countries in the ENP came late in the process. The slow implementation of the PCAs and the lack of progress in conflict settlement and regional cooperation prompted a policy review. This implied further engagement in the area and a closer monitoring of developments which became clearer from 2003, the year that marked a "new beginning" for the EU with the launching of its first field missions. ${ }^{10}$ In this context,

9 European Neighbourhood Policy Strategy Paper, Communication from the Commission, COM (2004) 373 final (May 12, 2004), pp. 10-11 and 17.

${ }^{10}$ On the $1^{\text {st }}$ of January 2003, the first EU civilian crisis management operation under the ESDP, the European Union Police Mission (EUPM) was deployed in Bosnia and Herzegovina, to which several others followed. The military operation in the Former Yugoslav Republic of Macedonia (Concordia), the military operation in the Democratic Republic of the Congo (Artemis) and the Rule of law mission in Georgia (Eujust Themis) have already terminated. Currently, the EU keeps a military operation in Bosnia and Herzegovina (EUFOR-Althea), the Police Mission in the Former Yugoslav Republic of Macedonia (EUPOL- 
the European Parliament called for a EU strategy for the region, advancing at the time the idea of nominating a special envoy for the area. The electoral processes in the three countries in 2003 were seen as a window of opportunity for political change which the EU should not miss, taking the chance to empower a common strategy towards the region.

Heikki Talvite was appointed as the EU Special Representative for the South Caucasus in 2003, and in July 2004 the first EU Rule of Law Mission was deployed in Georgia, ${ }^{11}$ demonstrating growing political willingness for a stronger EU presence in the area. Nevertheless, the negotiations on the Actions Plans have been progressing at a slow pace, with a first round of talks held before Christmas 2005, a second one in March 2006, and a third planned for the end of May. According to EU sources, this phasing of negotiations owes to the fact that the Plans "cover a very wide range of policy areas and each of the difficult chapters has to be tackled and they have a number of very precise points within them". ${ }^{12}$ But the lack of a cohesive and well-defined EU strategy for the area might also be a factor hampering the negotiations, as further analyzed.

The strategic importance of the region in economic, and particularly energy resources, should also be underlined. Parallel to political-democratic efforts, the EU has been promoting initiatives aimed at enhancing its presence in terms of trade, transport and energy, through the implementation of technical assistance programs, particularly TRACECA and INOGATE. ${ }^{13}$ The goal is to develop energy transport corridors (oil and gas), linking Europe to the Asian markets, crossing the Black Sea, the Caucasus, the Caspian Sea and Central Asia. It is also one of promoting regional integration of the pipelines' systems, working both as a catalyst for regional cooperation and as a confidence-building measure, much needed in a setting of instability. Economic assets, in particular energy resources, might either prompt further cooperation or instead foster competition, thus a delicate matter in need of careful handling.

This deeper commitment was also framed within the contours of the wording of the security strategy presented by Javier Solana at the Thessalonica Council in June 2003, entitled "A Secure Europe in a Better World". Defining the general

Proxima); a Police Mission in Kinshasa and a Security sector reform mission also in the Democratic Republic of Congo (EUSEC-GRD-Congo) (EUPOL-Kinshasa); an integrated Rule of law mission in Iraq (Eujust-LEX); a civilian-military support mission to the African Union mission in the Sudanese region of Darfur (AMIS II) and the monitoring mission to Aceh, Indonesia (AMM).

${ }_{11}$ Council Joint Action 2004/523/CFSP on the European Union Rule of Law Mission in Georgia, EUJUST THEMIS (June 28, 2004); EU Council, Political and Security Committee Decision Themis/1/2004 concerning the appointment of the Head of Mission of the EU Rule of Law Mission in Georgia, in the context of ESDP, EUJUST THEMIS (2004/540/CFSP) (June 30, 2004).

12 Emma Udwin, European Commission spokeswoman, cited in: "South Caucasus: Slow Progress on Plans for Closer EU Ties," RFE/RL (March 9, 2006).

13 TRACECA - Transport Corridor Europe, Caucasus, Asia - was established in Brussels in 1993 and has currently a permanent office in Baku. INOGATE - Interstate Oil and Gas Transport to Europe - is a EU program put in place through the INOGATE Umbrella Agreement, signed in 1999. 
principles for common external action, it identified as the main threats to peace and security, the spread of weapons of mass destruction, organized crime, failed states and terrorism. The priorities identified include the extension of the zone of peace and security to all of Europe; promotion of effective multilateralism, through the strengthening of the international order and on the basis of multilateral institutions and international law; and response to the new threats to security, focusing on its dynamic character and on the need to deal with them in a preventive way, through political and economic means. ${ }^{14}$ However, to achieve these objectives the Union's foreign policy has to be more active, more coherent (better coordination between the different decision-making levels), more capable (regarding the management of crisis, diplomatic capabilities and means of information), and developed in collaboration with other partners (such as the United States and Russia). Thus, the EU's neighborhood policy goals are closely interconnected with the principles defined in the Union's security strategy, demonstrating the commonly felt need for the building of stability in its vicinity as a way of promoting and expanding security.

In this definition of the Union's policies regarding its neighborhood, the combination of "good will gestures" and the fostering of principles at the core of the EU functioning, such as good governance, democratization and cooperation, with elements of "imposition" as concerns adjustments in ways and practices, has elicited disparate reactions. These have ranged from interpretations of the wider Europe policy as "mitigation of negative enlargement impacts on new border regions; rhetorical, low cost diplomacy to try and placate the excluded; [and] transformation of the states of the rest of Europe in line with common European values and with the benefits of progressive integration. The first objective is worthwhile but not strategic. The second is unworthy cynicism, to be rejected. The third is the strategic objective, which political scientists term 'Europeanization'."15 Whether the EU normative dimension will become explicit or whether Europeanization ${ }^{16}$ will be coined with "coercive imposition" is an interesting question to be followed.

For long the civilian nature of this normative actor was seen as its weakness, with the weight of historical dependence on the North Atlantic Treaty Organization (NATO) and the United States as Europe's security umbrella, preventing it from having a stronger stance on political-military and defense issues. This weakness reinforced the idea that the EU image as a coherent foreign and security actor was not more than a mirage. However, developments in the international stage and

\footnotetext{
14 Javier Solana, "A Secure Europe in a Better World," Thessaloniki European Council (June 20, 2003).

15 Michael Emerson, "Deepening the Wider Europe," Centre for European Policy Studies (CEPS) (February 24, 2004)

${ }^{16}$ Ibid.
} 
within the EU demanded a new positioning and further capacity to act, as revealed in the rendering operational of CFSP and ESDP commitments, allowing the Union enlarged capacity for action. So, not only was the civilian and normative character of the EU not erased, but also understood as a fundamental asset in the Union's dealings with its periphery, building on the EU's soft security approach. This includes supporting reforms towards democratic transition and stabilization, along with enhanced power through new deployment and involvement capabilities, conferring on the Union a stronger stance to act and respond in areas directly connected to its security. The Union's involvement in the southern Caucasus is also an example of this proactive approach.

The conflicts in the Caucasus, dating back to the old days of the Soviet Union and the context of its dismemberment, have been dealt with by international organizations, namely the UN and the OSCE, groups of states such as the Minsk Group regarding the settlement of the Nagorno-Karabakh conflict (co-chaired by Russia, France and the United States, under the OSCE auspices) and the Group of Friends of the UN Secretary-General for Georgia, and non-governmental organizations, along with second track mediation efforts by informal actors. The European states participate in these arrangements but only with the inclusion of the southern Caucasus in the ENP did their engagement become better framed, with the EU becoming an active player in the area. This is an innovative aspect of the ENP: the wish to set a holistic guiding-framework for its neighborhood, as a special category in its external relations. An objective broad in its goals and encompassing in its subjects, carrying with it the challenges associated to including a very different set of countries within the same policy-label, as further analyzed with regard to the Caucasus.

\section{THE EU AND THE CAUCASUS: SEARCHING FOR COMMONALITY IN A} PATCHY SCENARIO

The end of the Cold War and the dismemberment of the Soviet Union had a profound impact on the politico-strategic policies of the Caucasus. New states have emerged following the collapse of the Soviet empire, along with new opportunities and problems. The collapse of the artificial unity resulting from the Soviet ruling power unleashed old disagreements that, in several places, have escalated into armed confrontation. Both of an intrastate and inter-state nature the conflicts in the southern Caucasus have been a source of instability in a much disputed region. The secessionist conflicts within Georgia in Abkhazia and South Ossetia, and the dispute between Armenia and Azerbaijan over Nagorno-Karabakh are inscribed in this 
context of instability, further aggravated by the proliferation of illegal practices, such as trafficking in arms, organized crime, migratory flows and terrorism. In the face of these multidimensional threats, combining hard and soft elements, how the EU has been rendering operational its commitments to the stabilization of the region is a demonstration of its perception of threats and needs in the area, of the intersection between normative considerations and hard power policies, and of a simultaneously proactive and reactive nature of its responses. This reasoning is complemented by an analysis of how these countries and the region as a whole respond to the Union's approaches.

In general, the EU's approach to the south Caucasus has been a regional one, though after the independences of Armenia, Azerbaijan and Georgia were consolidated, and the differences between them surfaced with the erosion of the Soviet imposed harmonization, a differentiated approach to the problems of each of these countries was demanded. This is a principle upon which the ENP is based, through the negotiation of the Action Plans and which is complemented by a regional focus on stabilization and cooperation, which in instances collide, rendering the EU approach towards the area difficult to discern. On the one hand, it offers bilateral negotiations through the Action Plans mechanism, but on the other hand it addresses the region as a whole (the above mentioned holistic framework), in a regional approach that not always fits well the local political, social and economic mismatches. Thus, the southern Caucasus has been described as suffering from a "proximity-distance paradox"17: it is not so close to the EU core that its problems are clearly perceived and addressed by the European states, but it is not so far away as to be irrelevant, constituting both a source of opportunities due to the region's natural resources and potential market, and of instability, given the nature of political regimes, the ongoing conflicts and regional mistrust.

This regionally differentiated approach promoted by the EU has at times conflicted with its desire to promote regional cooperation, as was the case when disagreements between Azerbaijan and Cyprus led to the suspension of the negotiations of the Action Plans with the three southern Caucasus countries. ${ }^{18}$ This linkage was largely condemned by Armenian and Georgian authorities, who believed their negotiations should have gone ahead, independently of the problems that emerged with the Azeri authorities. This EU positioning reveals careful dealings

17 Dov Lynch, "The European Neighbourhood Policy and Georgia", Communication at the International Conference Georgia and European Integration, Sheraton Metekhi Palace, Tbilisi (September 30, 2005).

${ }^{18}$ On 27 July 2005, a private Azeri company flew a commercial flight to Northern Cyprus that, according to the authorities in Nicosia, violated Cyprus national sovereignty. Demands of harsh measures against Azerbaijan were voiced to Brussels. As a consequence, the Azerbaijani Cooperation Committee meeting in the fall of 2005 was canceled, and the Georgian and Armenian ones were delayed. Azerbaijan has already stated the return to normality in its diplomatic relations with Northern Cyprus ("South Caucasus: Slow Progress on Plans for Closer EU Ties," supra note 12). 
with a reality that is new for the Union, a tone of unwillingness to assume a level of differentiation towards the region, and the simultaneously felt need to respond to particular challenges, along with the type of restraints ENP progress is under. The ENP Strategy Paper states this need for differentiation which should be reflected in the Action Plans, taking into account "geographic location, the political and economic situation, relations with the European Union and with neighbouring countries, reform programmes, where applicable, needs and capacities, as well as perceived interests", while also stressing that it should simultaneously be based on a commitment to shared values and be compatible with a coherent regional approach. ${ }^{19}$ The stated aims that have been revealing are not always easy to reconcile.

This attempt at a regional approach by the EU has been met by an objective differentiation of positioning by Tbilisi, Yerevan and Baku. There is little information exchanged between the three capitals, and coordination efforts have been supplanted by competition, since each of these states attaches differentiated degrees of importance to the ENP. ${ }^{20}$ For Armenia, it is a way of breaking from isolation and getting financial assistance; for Azerbaijan, which originally was not so enthusiastic, it has been a way of maintaining an independent and balanced foreign policy vis-a-vis Moscow and Washington. But the inexistence of diplomatic contacts between Armenia and Azerbaijan renders the setting complex with no regional cooperation initiatives. Despite Brussels belief that the Action Plans might promote regional cooperation and foster neighborly relations, creating a more favorable context for peace talks and acting as a confidence-building measure, particularly regarding the Karabakh conflict, in fact thus far they have not been able of managing more than the usual deaf talk between Armenia and Azerbaijan. Armenia does not want to include Nagorno-Karabakh in the Action Plan, and Azerbaijan will not undergo regional cooperation without a lasting solution to the problem, so the frozen status of the conflict remains without a solution at sight in the face of inflexibility and the irreconcilable positions of the parties, leaving the EU with a very limited space for manoeuvring.

Adding to this difficult regional setting, Georgia has advanced a new notion of regional cooperation, not within the southern Caucasus (and thus departing from a regional framework in which the Georgian authorities do not trust), but within the Black Sea region. Tbilisi has managed to gather a group of supporters (the New Group of Friends of Georgia) including the three Baltic states, Bulgaria, Poland and

\footnotetext{
${ }^{19}$ European Neighbourhood Policy Strategy Paper, supra note 9, p. 8.

20 A clear exception was a meeting that took place in Tbilisi in early 2006, between the Georgian and Armenian Foreign Ministries, where the possibility of developing joint ownership and regional cooperation was stressed as a positive development.
} 
Romania on what has been called a Baltic Sea-Black Sea axis. ${ }^{21}$ In addition, the Georgian authorities have requested a differentiated approach from the EU, an "individual treatment", 22 particularly after the 2003 political turn, which further adds to the region's mismatches. Georgia's Action Plan negotiations with the EU have followed the Ukrainian model, which Georgia perceives as very similar to its own: ${ }^{23}$ there is a sharing of aspirations regarding European integration and both perceive their independence as dependent on western support, particularly regarding Russian interference in their internal affairs, either directly or indirectly through political, economic or social pressure. But this has also misled Russia in its relations with the authorities in Tbilisi. "In fact, [Russians] used military methods: force and blackmail. And, as a consequence, they [currently] find they have no flexibility of action. And the main result is that they now have this hard, relentless opposition in the form of president [Mikhail] Saakashvili and his team."24

This regional diversity and lack of cohesiveness demand from the EU differentiated approaches in a common normative and stability oriented strategy. Thus, the EU contribution to regional development through conflict settlement and the implementation of democratic reforms should not be a linear and rigid process, but a multilayered and adjustable one. Nevertheless, the question whether the EU has the means and the political willingness necessary to implement such a flexible strategy, and whether the Action Plans in the context of the neighborhood policy might be effective instruments for accomplishing the Union's goals for the southern Caucasus, remains to be seen.

In addition, the three countries should build common ground on how and whether they stand towards the EU, starting from a clear definition of their specificities along with the possible framing of regional cooperation. "[C]rucial issues like the 'region-ness' of the south Caucasus will have to be discussed in order to determine where the societies of the south Caucasus currently are, where they want to go and whether it makes sense at all to discuss a possible movement closer to the European Union in categories like 'region'."25 Thus, a common regional approach might have to be based not so much on the search for a common identity or for shared political cultures, but more on pragmatic aspects of cooperation in political and economic terms that might suggest rapprochement, eventually building

21 "Baltic Sea-Black Sea 'Axis' Adumbrated," Eurasia Daily Monitor Vol.60 (2) (March 28, 2005); "New Group of Georgia's Friends founded," Eurasia Daily Monitor Vol.2 (26) (February 7, 2005).

22 Mariam Dekanozishvili, "Regional Preconditions for the Development of an Integrated European Policy Towards the South Caucasus," Documentation of the Conference at the Heinrich Böll Foundation, Tbilisi (June 1-2, 2004): 12.

${ }^{23}$ Speech of the State Minister of Georgia on European and Euro-Atlantic Integration, Giorgi Baramidze, Paris (December 21, 2005).

${ }^{24}$ Aleksandre Rondeli, Georgian Foundation for Strategic and International Studies cited in: "Analysis:

Putin Seeks to Draw Azerbaijan Back into Russian Orbit", RFE/RL (February 21, 2006).

${ }^{25}$ Mariam Dekanozishvili, supra note 22: 3. 
on the energy resources in the region (exploitation, transit and delivery), and certainly conferring added pressure to the resolution of the conflicts in the area.

\section{GEORGIA}

The November 2003 "Rose Revolution" in Georgia, was hailed as a new beginning for the country. President Eduard Shevardnadze stepped down from office, and Mikhail Saakashvili came to power with promises of a reformist course following democratic lines. The EU applauded this political change and in January 2004, Javier Solana, the EU High Representative for the CFSP travelled to Tbilisi with a package containing financial assistance to support the new government's reform plans, particularly anti-corruption initiatives. ${ }^{26}$

The EU's concern has been expressed in a rapid response to Georgia's request for assistance to the reform of its judiciary system with the expeditious deployment of a Rule of Law Mission in the country. In the words of Javier Solana, it is "key to ensuring stability and also growth", demonstrating both that the EU is fully committed to supporting Georgia, and that it can react quickly. ${ }^{27}$ Following the principles of the Country Strategy for Georgia (2003-2006), and as a part of the EU support to transition, the mission activities focused on assistance in the reformation of the judicial system, particularly criminal legislation, working in close collaboration with the national authorities, in order to bring local standards closer to international and EU standards. The mission was closed in July 2005, after a year of deployment described as successful, ${ }^{28}$ leaving a strategy in place for the Georgian government to implement, which will be part of the ENP Action Plan.

The EU involvement in the search for a solution to the internal conflicts in Georgia has been minimal, since a division of labor has been in place between the OSCE and the UN. This arrangement goes along with the European security strategy objectives of multilateralism, though it is still not clear how to enhance the presence of the EU through a coordinated effort of its neighborhood policy mechanisms with the international organizations in the field. Some timid signs of collaboration have been given with the EU support to the OSCE Border Monitoring Operation, along with assistance to the negotiations regarding the Georgian-South Ossetian conflict, the former more explicit than the latter. It is expected that the culmination of the negotiations regarding the EU Action Plan towards Georgia in

\footnotetext{
26 "Georgia: Solana Visits Tbilisi to Show EU's Support for New Leaders," RFE/RL (January 15, 2004).

27 Message from Javier Solana, EU High Representative for the CFSP, on the occasion of the launch of the mission EUJUST THEMIS in Georgia, S0199/04, 23 (July 2004).

${ }_{28}$ Briefing by the Head of Mission on the Successful Conclusion of EUJUST THEMIS, EU Council Secretariat, THE/03 (update 3) (July 22, 2005).
} 
2006, along with the extension of the mandate of the EUSR, might bring clarity to the issue and allow further EU involvement.

In Abkhazia problems date back to 1993, when Abkhaz separatists seized control of this region of Georgia, fighting the central government for its control. The displacement of most ethnic Georgians inhabiting the region, with Russian military support, further encouraged the secessionist claims. The government of Georgia has offered extensive autonomous status to the region, however the separatists demand full independence. The OSCE's positioning in this regard includes the offer of strong support for the sovereignty and territorial integrity of Georgia within its internationally recognized borders, while searching for ways to accommodate Abkhaz aspirations. A cease-fire was brokered with Russian assistance, Russian peacekeeping forces have been stationed in Abkhazia under the CIS authority, and the UN deployed a mission to provide good-offices (UNOMIG), while the OSCE remained marginal to the negotiations. The situation remains unstable despite the attempts at re-launching the process. Most recently, on 29 March 2006, the Georgian authorities and the republic of Abkhazia agreed to resume talks and revive the Georgian-Abkhaz Coordinating Council, which saw its activities suspended in 2002 - a move that follows a series of blasts and increasing instability in the breakaway region. ${ }^{29}$

South Ossetia declared its independence in September 1990 and convened parliamentary elections, a ballot not recognized by the central government of Georgia, and which led to an escalation into armed conflict in January 1991. South Ossetia demands total independence, a claim refused by Tbilisi. In the August 1995 Georgian Constitution, provisions on the territorial structure have been left open in order to leave room for negotiated solutions to the problems in Abkhazia and South Ossetia. The OSCE Mission to Georgia dealing with the South Ossetian conflict in co-operation with the Russian Federation managed to maintain the cease-fire in place and to lay down the key issues to be discussed and integrated in the final settlement accord, with full respect for the territorial integrity of Georgia. ${ }^{30}$ However, progress has been slow, with problems remaining at the legal, political and economic level to solve the issue of the return of refugees, and no agreement has been found on a special status for South Ossetia. The OSCE efforts have been reinforced by cooperation with the $\mathrm{EU}$, particularly in the implementation of economic rehabilitation projects, regarding which it has the mandate, but not the required financial resources.

\footnotetext{
29 "Georgia and Abkhazia Agree to Resume Bilateral Talks," RFE/RL (March 29, 2006); "Abkhazia Blames Georgia for Deadly Attack," RFE/RL (March 9, 2006).

${ }^{30}$ OSCE Budapest Document 1994, Budapest Decisions, Chapter II, Paragraph 3.
} 
The talks between Georgian central authorities and Ossetian representatives are due to resume, after many ups and downs in diplomatic contacts. ${ }^{31}$ The situation has hardened and Moscow has increasingly been assuming an assertive tone, playing against Tbilisi and using support to the separatists as leverage power and pressure over the Georgian authorities and their new politically western looking approach. Georgia has asked for the withdrawal of the Russian peacekeeping troops from the area, which it understands as perpetuating instability. Eduard Kokoity, the South Ossetian president is against the withdrawal of Russian troops. "We are a sovereign state, a state that is independent from Georgia. Apart from Russian peacekeepers, no one will be stationed on the territory of the republic of South Ossetia. Those countries that have already responded favorably to the Georgian proposal should think twice. We have in mind here Ukraine and the Baltic states. Even morally, those states have no right to send peacekeeping contingents here, because they are supporting Georgia, they are arming Georgia." 32 EU diplomats have already voiced their concern about the possibility of the Georgian authorities recurring to the use of force against the region, in an effort to put an end to the secessionist claims. But these voiced concerns have not been matched by resolute action from the Union, which has been dealing with Georgia much on the basis of a "wait-and-see" approach.

Last year Tbilisi addressed a request to the EU for a full border-monitoring mission in South Ossetia, without success. Georgia would also like to have a EU commitment to fund the post-conflict rehabilitation processes in South Ossetia and Abkhazia. But the EU, which aiready supports displaced persons in the area, has made as a previous condition to any funding arrangement, the resolution of the conflicts. This ambivalence contains ingredients of both support and reluctance. On the one hand, the EU is committed to Georgia's transition process, as proved in the extension of the mandate of the EUSR. This, nevertheless, does not mention the Special Representative involvement in the conflict resolution process, though pointing to the possibility of the EU getting more involved on border issues, especially in South Ossetia. ${ }^{33}$ On the other hand, the EU does not want to become deeply embedded in the country's problems, particularly the conflicting zones. And in this regard the unwillingness of some of the EU member states to antagonize Russia should not be overruled.

\footnotetext{
31 "Georgian-Ossetian Talks to Resume," RFE/RL (March 27, 2006).

32 Eduard Kokoity, South Ossetian president, cited in: "Georgia: Tbilisi, Moscow at Odds over South Ossetia Revolution," RFE/RL (February 16, 2006).

${ }_{33}$ Ibid.
} 


\section{ARMENIA AND AZERBAIJAN}

Armenia has been stating at the highest level its European vocation, which the EU recognizes as an added value in its assistance to the country regarding democratization and economic development. Armenian foreign policy towards the EU is described as a policy of "complementarity", where the authorities in Yerevan seek closer cooperation with the Union as an important part of its national objectives. Yerevan has difficult relations with its neighbors, particularly Azerbaijan and Turkey, with which it does not have diplomatic relations, as well as with Georgia and Russia. Political independence came in 1991, but Armenia remained rather dependent on Russia both economically and militarily. Currently, Armenia sees the EU as an important partner to counterbalance the rising importance of Turkey and Azerbaijan (rich in energy resources), along with the declining power of Moscow in the regional context. Moreover, EU assistance is welcomed in the face of difficult economic conditions and the unresolved conflict with Azerbaijan over Nagorno-Karabakh.

Azerbaijan has maintained a balanced foreign policy between the west and Russia, avoiding direct dependence on any of them, and resorting to energy resources as an attractiveness factor. The United States lifted the ban it had imposed on Azerbaijan back in 1992 under the Freedom Support Act, ${ }^{34}$ recognizing its central place in energy matters in the Caucasian geostrategic game, arguing as a result that a perpetuation of the ban would not let democracy flourish, hampering the conditions for the finding of a political solution to the conflict with neighboring Armenia. In this setting, high-level diplomatic relations between Washington and Baku are gaining momentum, with the visit of President Ilham Aliyev to Washington in April 2006 marking Azeri growing international importance in geostrategic and economic terms. ${ }^{35}$

Brussels has been more cautious on its dealings with Baku, due to the nature of the local regime, often accused of violating fundamental liberties, in contradiction with the Union's constitutive power based on the sharing of a set of values and underlying normative principles for its conduct, from which Azerbaijan seems distant. However, the geostrategic location of Azerbaijan along with the vastness of its natural resources cannot be overruled by the EU, and are factors that directly implicate with the kind of conditionality the EU is ready to put in the ENP towards Azerbaijan. The final wording of the Action Plan to be agreed between the EU and Azerbaijan most certainly will reflect this.

\footnotetext{
${ }^{34}$ Freedom Support Act (1992), provision 907.

35 "Geopolitics Wins Aliyev First White House Visit," Financial Times (April 25, 2006).
} 


\section{THE NAGORNO-KARABAKH CONFLICT AS A PIECE IN THE COMPLEX CAUCASIAN PUZZLE}

Nagorno-Karabakh, an ethnically Armenian enclave within Azerbaijan, witnessed a stage of armed confrontations between 1988 and 1994. After a ceasefire was reached, the search for a political settlement to the conflict has been difficult due to the parties' irreconcilable demands. While Nagorno-Karabakh demands full independence, Azerbaijan conceives only of granting a broad autonomous status to the enclave. Azerbaijan demands withdrawal of Armenian forces and the restoration of the country's territorial integrity before discussing issues such as the Karabakh status or the re-establishment of economic relations with Armenia. The core of the conflict is territorial and a solution must preserve Azerbaijan's territorial integrity and sovereignty, granting self-governance to the Karabakh people within the Azeri state. Moreover, Baku considers NagornoKarabakh is not a party to the conflict, since the latter is a dispute between Armenia and Azerbaijan; thus it does not envisage conducting negotiations with the enclave's leaders. All official acts taking place in Nagorno-Karabakh, including elections and referenda, are not recognized by the Azerbaijani authorities, who describe them as having no international legal effect.

For Armenia, Nagorno-Karabakh "will never be a part of Azerbaijan". ${ }^{36}$ Yerevan is not willing to discuss withdrawal from Azerbaijani territories until Nagorno-Karabakh is recognized as independent. For the Karabakh authorities, a peace settlement must have the republic's consent, thus its participation in the negotiations is considered mandatory, and must not entail vertical subordination to Baku. For Askadii Ghukasian, president of the unrecognized republic, NagornoKarabakh has to be a part of the talks. ${ }^{37}$

Armenia has been supporting Stepanakert with economic and military assets, rendering the secessionists position more inflexible, and aiming at the country's participation in any relevant oil transportation systems that might be defined for the area. The natural resources of the region, particularly the discovery of large hydrocarbon fuel reserves and the construction of pipelines in the proximity of the area in conflict, are fundamental elements in the protracted character of the negotiations, where both parties demand economic, strategic and political advantages from a negotiated solution, opposing interests that have been hard to reconcile. In addition, Karabakh Armenians have been "independent" for more than ten years, calling into question the advantages of signing an agreement worse than

\footnotetext{
36 Armenian President Robert Kocharian, cited in: "Armenia/Azerbaijan: OSCE to Rekindle NagornoKarabakh Talks," RFE/RL (March 6, 2002).

37 "Azerbaijan Again Rules out Talks with Karabakh Officials," RFE/RL (July 2, 2003).
} 
the present compromise. The attributes of statehood, internal sovereignty and empirical statehood are no longer negotiable in practice.

The attempt to re-launch the peace process in Rambouillet, in February 2006, did not produce any advances, despite the support of the OSCE Minsk Group (United States, Russia, and France) and the personal involvement of French President Jacques Chirac, who met the two leaders separately before the official talks - Robert Kocharian and Ilham Aliyev, from Armenia and Azerbaijan, respectively. Declarations at the end of the meeting signaled that the negotiations might have reached a stalemate and Aliyev's statements recently might raise questions as to the consequences of the increasing disparity in the military and defense budgets of the two countries. "Politicians think only about their political destiny, statesmen think about the future of the nation. We think it's time for Armenia's leadership to behave like statesmen, to think what will happen in five years, in 10 years, in 15 years if the conflict will not be resolved. [The] patience of the Azerbaijani people has limits." ${ }^{\prime 38}$ The frozen status of the conflict has been giving ground to a warming of tension with gunfire exchanged in the front line, in the most serious outbreak of violence in the region since the signing of the ceasefire agreement.

The EU has been present at the negotiations through its member state France (co-chairing the OSCE Minsk Group), and its Special Representative for the South Caucasus, who has also been working on bringing the parties together and gathering regional and international support for a peaceful and final solution to the conflict, though within severe contextual limits.

For the EU, stability in the Caucasus is fundamental as concerns an alternative provider of energy resources, and in the global fight against terror, justifying its increased involvement in the region's problems. "In all of these conflicts, we have not had substantial progress for too long, and we think that this is not only a great problem for the populations concerned - both politically and economically - but a source of threat to the international community, which the international community can no longer afford." ${ }^{39}$ The EU has been extending its support to the area, mainly through economic channels. Underlining the advantages that might arise from the finding of a political settlement, particularly regarding economic aspects and social development, the EU's pressure over the energy assets of the region might constitute a catalyst for progress in the Karabakh negotiations. In fact, the international market for Azerbaijani oil has been growing, demonstrating the

\footnotetext{
${ }^{38}$ Azerbaijani President Aliev cited in: "Azerbaijan: Aliyev Defends His Records on Rights," RFE/RL (April 26, 2006)

39 Diego D'Ojeda, European Commission spokesman, cited in: "Caucasus: Is the EU Neglecting the Region's Strategic Importance?" RFE/RL (March 13, 2003).
} 
prospects of economic recovery if peace prevails ${ }^{40}$. However, the economic factor might play either to the pacification of the situation or instead to an aggravation and deterioration of the conditions. It might be a fundamental bargaining element towards the finding of a political settlement, since the perpetuation of the conflict hampers economic recovery and further relations in the area; but it might also negatively condition the negotiations process given the international high demand for oil and gas, which might be played in this case by Baku to its most advantage. So, the way this economic factor will be used in the negotiations will be a fundamental aspect in the clarification of positions and bargaining elements in the stabilization of the Caucasus.

"The new 'great game' for Caspian oil made the three states of the region 'local players' in the geopolitics of the South Caucasus", rendering the political setting to follow economic and geopolitical lines rather than cultural and geographical aspects ${ }^{41}$. Regional powers, such as Iran and Turkey, as well as Russia, the United States and the European Union have all voiced their concern for the continuing hostility. The search for a settlement as a precondition for stability in the Caucasus is generally understood by these states as a prerequisite for the building of security. The content of this settlement, however, reveals the differences regarding politico-economic and strategic options and the overlapping interests of these countries regarding the area's energy resources. ${ }^{42}$

Turkey and Iran as neighbouring countries of the conflicting area are concerned about the possible resumption of armed hostility as a way of deepening antagonism, rendering more difficult the achievement of a political settlement, and most probably causing a new wave of refugees, with direct consequences to their economies and domestic stability. While Turkey has been pro-Azerbaijani, supporting Baku militarily, economically and diplomatically, Armenia has been getting support from the Iranian government. The partiality of these countries towards the Nagorno-Karabakh conflict does not allow hopes for a constructive neutral engagement in any resolution proposals.

As for Russia, its interests in the area are well known. For the past two centuries Russia has been a protector of Armenia and its most important ally. It envisages keeping control of energy resources and maintaining its military bases in the country, while avoiding an enlarged involvement by third states. The existing strategic and military cooperation between Yerevan and Moscow is seen in Armenia

\footnotetext{
40 Brenda Shaffer, "Nagorno-Karabakh: Writing a UN Wrong," Christian Science Monitor (May 21, 2003) // http://www.csmonitor.com/2003/0521/p09s02-cojs.html (accessed October 19, 2013).

41 Revaz Gachechiladze, "Geopolitics in the South Caucasus: Local and External Players," Geopolitics Vol. 7(1) (2002): 114-115.

42 Maria Raquel Freire and Teresa Cierco, "Regional Security and the Nagorno-Karabakh Conflict," Nação e Defesa No. 110 (2005).
} 
as an important factor for the country's economic progress and as a guarantee of its security. ${ }^{43}$ The territories of Georgia, Armenia, Azerbaijan and the secessionist Nagorno-Karabakh serve as a buffer for Russia against intrusion from Turkey and Iran. Therefore, it is in the interest of Russia to minimize the influence of the latter two countries in the region and to extend its military power in the Caucasus. Additionally, Russia not only seeks to profit economically from the oil and gas reserves under the Caspian sea, but also to gain some form of control over the energy sources and lines of supply in the Caspian basin as an instrument of global power. ${ }^{44}$ Thus, Moscow carefully balances its relationship with the west, with the maintenance of political, military and economic influence in the Caucasian region.

The intricacy of the issues regarding the Nagorno-Karabakh conflict demands an innovative approach ranging between broad autonomy and independence. The international community faces, therefore, the task of creating a new reasoning that addresses the logic driving the self-declared states, in order to be able to respond effectively to the current demands. The most pressing issues include the definition of a formal status for the Nagorno-Karabakh Republic; the addressing of Stepanakert demands as regards security guarantees as a condition for the Armenian withdrawal from the occupied territories; provisions for the safe return of refugees; and the role and composition of the peacekeeping forces to monitor the agreement as well as international guarantees. A long-term solution to the conflict must therefore entail a balanced response to the opposing demands of the parties, and take into account the regional context of cooperation and competition in order to gather the necessary consensus, even if as a minimum common denominator, to be acceptable and accepted.

\section{THE EU AND THE CAUCASUS: AN ASSESSMENT}

Besides finding internal balance, in addressing the current security challenges, the EU must attend to its new geographical limits, stretching to Russian borders and the former Soviet area, and having as "outsiders" countries such as Moldova, Ukraine and Georgia, which already have shown interest in joining the organization. Aiding these states in their transition course, a difficult challenge particularly with regard to poor governance, lack of political and institutional stability, and economic and social problems, to which the ongoing conflicts add a further element of complexity, may constitute an important step forward in enhancing European

43 Ministry of Foreign Affairs of the Republic of Armenia, "Armenia's Foreign Relations in 2003: A Summary" (2003): 3.

44 "The Nagorno-Karabakh Crisis: A Blueprint for Resolution," A Memorandum Prepared by the Public International Law and Policy Group and the New England Center for International Law and Policy, Washington DC (June 2000): 11. 
security. It might be so by promoting transparency and democratic principles while fighting illegal trafficking in arms, drugs and alcohol, and widespread corruption, practices favourable to unstable governance and to the rooting of terrorist and illicit-based networks.

In fact, the EU's political-economic and civilian role, including policing, enhancing the rule of law, civil administration, the promotion of good governance and respect for human rights - known as "soft areas" -, has made a difference in different areas, with the EU response to new and old challenges being solidly constructed over non-military means. The EU is a relevant foreign player in the south Caucasus: it has been a provider of financial, technical and humanitarian assistance, and it has shown willingness to deepen its presence, helping to "reinforce stability and security and contribute to efforts at conflict resolution", as well as to strengthen "the EU's contribution to promoting the settlement of regional conflicts". ${ }^{45}$ However, the Country Reports only vaguely mention this objective, in line with the promotion of international peace and security, and the recommendations from the Commission restricted its commitment to economic rehabilitation of conflict zones, ${ }^{46}$ thus not clearly stating the EU's involvement in the political talks to the settlement of conflicts.

The bilateral negotiations of the Action Plans should give room to more intense cooperation in this area, but the EU has shown wariness about this option, rejecting Georgia's request for the Union to play a more active role in crisis management, namely in South Ossetia, requiring deeper political-military and security involvement. Georgia has been swift in internationalizing its conflicts, and presenting its case in international fora, such as at the UN and the OSCE, taking advantage of the renewed attention it gained from 2003, after the political twist in the country. In this line, it has asked for EU and US support, having been involved in international missions in Kosovo, Afghanistan, and Iraq, ${ }^{47}$ and seeking to implement consistent reforms in its defense sector. The EU faces in Georgia one of its biggest challenges, at a time when the definition of its role as a security actor is under close scrutiny and much expectation. The successful conclusion of the Rule of Law Mission to Georgia might be a first good step in this direction, but the permanence of the EU in the field along with the developments it might inspire will certainly be crucial in any assessment of its role as both a monitoring agent and active player in the region.

${ }^{45}$ European Neighborhood Policy Strategy Paper, supra note 9, pp. 4, 6.

${ }^{46}$ European Neighborhood Policy: Recommendations for Armenia, Azerbaijan, Georgia and for Egypt and Lebanon, Communication from the Commission, COM (2005) 72 final (March 2, 2005).

${ }^{47}$ Speech of the State Minister of Georgia on European and Euro-Atlantic Integration, Giorgi Baramidze, Paris (December 21, 2005). 
To Armenia, greater EU involvement is a means of breaking its regional isolation and, as such, it has initially requested EU assistance regarding the ceasefire in Nagorno-Karabakh, and then raising the stakes and asking for political support to solve the conflict. Azerbaijan, assuming a more distanced tone, has not asked for direct EU involvement in the resolution of the conflict since it has been disappointed with the Union's unwillingness to clearly state the Armenian occupation of Azeri territory. ${ }^{48}$ The EU has insisted that a solution should be found within the OSCE Minsk group framework, offering limited assistance to the process, now strengthened by the presence of the EUSR. Azerbaijan has maintained a selfsustaining and distant foreign policy between the west and Russia, avoiding direct dependence on any of them. Its privileged position as an oil producer confers on Baku added leverage power, which Yerevan lacks, and Tbilisi struggles for.

The Union's neighbourhood has become a priority for EU action in a realist perception of European problems and capabilities, as the European security strategy indicates in its offering of a framework for action to render the EU more operational and effective.

Small steps need to be taken, on the basis of accorded priorities and the definition of common strategies. In this sense, the ENP still has to demonstrate how it will conciliate regional differentiation with the promotion of regional cooperation, and the extent to which the sharing of European values can be conciliated with the weight of history, and the specificities of this much diversified region.

"[T]the EU is more 'fashionable' and by all means wealthier club of nations. The EU offers a unique combination of economic power and possibilities for a political dialogue. This may be an added value to conventional multilateral diplomacy under UN or OSCE auspices. (...) [T] he EU could much more effectively than others pursue a 'stick-and-carrot' policy putting its financial support under political conditionality liked to progress in conflict resolution processes. ${ }^{\prime 49}$ However, the extent to which EU member states will demonstrate the necessary political will to an enlarged involvement, in a particularly unstable area where the intersection of competing interests has been clear, remains to be seen. Further involvement, closer monitoring, and eventually intensification in political and economic pressure through some form of conditionality associated with this deepened EU commitment to the area could make a difference in the building of stability in a much unstable region, despite all the known limits and restraints.

48 "Heikki Talvite: EU to Prepare Report on the South Caucasus Countries," AzerNews (November 11, 2004).

${ }^{49}$ Mariam Dekanozishvili, supra note 22: 9-10. 


\section{CONCLUSION}

The European Union's wish to gain more prominence in security matters has become real, but whether the commitment to render it truly operational will become a reality still remains to be seen. The Iraqi affair, as a practical example of the existing contradictions within the Union and of its consequent inability to formulate a common position on the issue, may serve as a lesson. The European Security Strategy might be an important part of this lesson, seeking to cope with a fundamental handicap-namely, the need for a map to help avoid further detours and directional missteps. Which lines of consensus will be developed and which will have an impact regarding security and defense, are fundamental questions not only for Europe but also at the global level. "It is not the words but the deeds that count in international politics. The EU has now accumulated political will and resources in order to start making a difference in the field of peace and security, as it is already doing in the global market." 50 Whether it will manage internal differences and gather the necessary support for an active engagement in security matters in its vicinity is still to be seen. The cards are on the table and the game has already started, but the rules are still not clear enough to allow the empowerment of a common, cohesive and directed strategy.

These endogenous difficulties have been dealt with in the effort to draw a regional-based policy towards the southern Caucasus, built on country to country reports and Action Plans. EU foreign and security policy in its vicinity has been broadened, with the appointment of a EUSR for the South Caucasus, its further involvement in economic and political transition processes, and attempts at clarification of the Union's relation with the Russian Federation. EU policies towards the Caucasus present both an opportunity and a challenge, carrying possibilities and limitations in the area and between the Union and Georgia, Armenia and Azerbaijan. The different rhythms of political transition, economic development, and external engagement are fundamental factors, along with the menaces associated with corruption, bad governance and trafficking in arms, drugs and people, which afflict the three states.

The strategic partnerships that might be drawn between the Union and these states and its framing in a regional strategy have revealed complexity. Agreement over the Action Plans might bring some clarity, though the balancing of a regional approach with the specificities of each of the Caucasian countries shows the difficulty in finding commonality in a patchy scenario.

50 "The European Security Strategy - The Next Steps?" Summary of address by Javier Solana, EU High Representative for the CFSP, Helsinki (February 25, 2004). 


\section{BIBLIOGRAPHY}

1. "Abkhazia Blames Georgia for Deadly Attack." RFE/RL (March 9, 2006).

2. "Analysis: Putin Seeks to Draw Azerbaijan Back into Russian Orbit." RFE/RL (February 21, 2006).

3. "Armenia/Azerbaijan: OSCE to Rekindle Nagorno-Karabakh Talks." RFE/RL (March 6, 2002).

4. "Azerbaijan Again Rules out Talks with Karabakh Officials." RFE/RL (July 2, 2003).

5. "Azerbaijan: Aliyev Defends His Records on Rights." RFE/RL (April 26, 2006).

6. "Baltic Sea-Black Sea 'Axis' Adumbrated." Eurasia Daily Monitor Vol.60 (2) (March 28, 2005).

7. Briefing by the Head of Mission on the Successful Conclusion of EUJUST THEMIS. EU Council Secretariat, THE/03 (update 3) (July 22, 2005).

8. Carlsnaes, Walter, Helen Sjursen, and Brian White. Contemporary European Foreign Policy. SAGE Publications, 2004.

9. "Caucasus: Is the EU Neglecting the Region's Strategic Importance?" RFE/RL (March 13, 2003).

10. Charillon, Frédéric. "The EU as a Security Regime." European Foreign Affairs Review No. 10 (2005): 517-533

11. Council Joint Action 2004/523/CFSP on the European Union Rule of Law Mission in Georgia. EUJUST THEMIS (28 June 2004).

12. Dekanozishvili, Mariam. "Regional Preconditions for the Development of an Integrated European Policy towards the South Caucasus." Documentation of the Conference at the Heinrich Böll Foundation. Tbilisi (June 1-2, 2004).

13. Emerson, Michael. "Deepening the Wider Europe." Centre for European Policy Studies (CEPS) (February 24, 2004).

14. EU Council, Political and Security Committee Decision Themis/1/2004 concerning the Appointment of the Head of Mission of the EU Rule of Law Mission in Georgia, in the Context of ESDP. EUJUST THEMIS (2004/540/CFSP) (June 30, 2004).

15. European Neighborhood Policy: Recommendations for Armenia, Azerbaijan, Georgia and for Egypt and Lebanon. Communication from the Commission, COM (2005) 72 final (March 2, 2005).

16. European Neighbourhood Policy Strategy Paper. Communication from the Commission, COM (2004) 373 final (May 12, 2004).

17. Freire, Maria Raquel, and Teresa Cierco. "Regional Security and the NagornoKarabakh Conflict." Nação e Defesa No. 110 (2005): 59-86. 
18. Gachechiladze, Revaz. "Geopolitics in the South Caucasus: Local and External Players." Geopolitics Vol. 7 (1) (2002): 113-138.

19. "Geopolitics Wins Aliyev First White House Visit." Financial Times (April 25, 2006).

20. "Georgia and Abkhazia Agree to Resume Bilateral Talks." RFE/RL (March 29, 2006).

21. "Georgian-Ossetian Talks to Resume." RFE/RL (March 27, 2006).

22. "Georgia: Solana Visits Tbilisi to Show EU's Support for New Leaders." RFE/RL (January 15, 2004).

23. "Georgia: Tbilisi, Moscow at Odds over South Ossetia Revolution." RFE/RL (February 16, 2006).

24. "Heikki Talvite: EU to Prepare Report on the South Caucasus Countries." AzerNews (November 11, 2004).

25. Lynch, Dov. "The European Neighbourhood Policy and Georgia." Communication at the International Conference Georgia and European Integration. Sheraton Metekhi Palace, Tbilisi (September 30, 2005).

26. "New Group of Georgia's Friends founded." Eurasia Daily Monitor Vol.2 (26) (February 7, 2005).

27. Paving the Way for a New Neighbourhood Instrument: A New Framework for Relations with our Eastern and Southern Neighbours. Communication from the Commission (July 1, 2003).

28. Samson, Ivan, and Olena Vasylchenko. "EU PCA and ENP Policies for Georgia: How Economic Interaction with the European Union May Ease the Reform Process and Economic Development in Georgia." Georgian Economic Quarterly Review No. 4 (2004): 101-116.

29. Shaffer, Brenda. "Nagorno-Karabakh: Writing a UN Wrong." Christian Science Monitor (May 21, 2003) // http://www.csmonitor.com/2003/0521/p09s02cojs.html (accessed October 19, 2013).

30. Solana, Javier. "A Secure Europe in a Better World." Thessaloniki European Council (June 20, 2003).

31. "South Caucasus: Slow Progress on Plans for Closer EU Ties." RFE/RL (March 9, 2006).

32. Youngs, Richard. "The ESDP: What Impact on the EU's Approach to Security Challenges?" European Security Vol.11 (2) (2002): 101-124.

33. White, Brian. "Foreign Policy Analysis and the New Europe": 11-31. In: Carlsnaes, Walter, Helene Sjursen, and Brian White, eds. Contemporary European Foreign Policy. SAGE Publications, 2004. 
34. Wider Europe Neighbourhood: A New Framework for Relations with our Eastern and Southern Neighbors. Communication from the Commission, COM (March 2003). 